\title{
Synthesis, Physicochemical and Antioxidant Properties of Some Metal(II) Complexes of Mixed Drugs, Aspirin and Nicotinamide
}

\author{
Aderoju A. Osowole*, Abiodun E. Odutemu \\ Inorganic Chemistry unit, Department of Chemistry, University of Ibadan, Nigeria
}

*Corresponding author: Aderoju A. Osowole, Inorganic Chemistry unit, Department of Chemistry, University of Ibadan, Nigeria, Tel: +2348097327529; E-mail: aderoju30@gmail.com

\begin{abstract}
The Drugs, Aspirin (HL) and Nicotinamide $\left(\mathrm{HL}^{3}\right)$, and their mixed metal(II) complexes were synthesized and isolated as $\left[\mathrm{M}(\mathrm{HL})\left(\mathrm{HL}^{3}\right) \mathrm{X}_{2}\right]$, where $\mathrm{M}=\mathrm{Fe}, \mathrm{Co}, \mathrm{Ni}$, $\mathrm{Cu}, \mathrm{Zn} ; \mathrm{X}=\mathrm{Cl}-\mathrm{SO}_{4}{ }^{2-}$. These complexes were characterized by spectroscopic techniques (IR \& UV-Visible), percentage metal, molar conductance, and melting point and room temperature magnetic moment measurements. The metal complexes were mostly non-electrolyte in DMSO with molar conductance values in the range 19.70 $46.80 \Omega^{-1} \mathrm{~cm}^{2} \mathrm{~mol}^{-1}$. Nicotinamide and Aspirin behaved as bidentate, coordinating to the metal ion through their carbonyl oxygen and pyridinyl nitrogen atoms respectively, as corroborated by infrared spectroscopy measurement. Electronic spectra indicated that all the metal complexes adopted octahedral geometry and magnetic data revealed that the $\mathrm{Mn}$ (II) and $\mathrm{Ni}$ (II) complexes were probably dimeric, while the remaining metal complexes were monomeric, diamagnetic or paramagnetic. In addition, the antioxidant study revealed that the drugs, Aspirin and Nicotinamide (Vitamin $\mathrm{B}_{3}$ ), and their mixed metal complexes had higher antioxidant activity than Ascorbic acid, the positive standard, thus confirming their potentials as anticancer agents in-vitro.
\end{abstract}

Keywords: Aspirin; Antiferromagnetism; Antioxidan; Nicotinamide; Spin-crossover
Received Date: August 28, 2016

Accepted Date: October 24, 2016

Published Date: October 31, 2016

Citation: Osowole, A.A., Odutemu, A.E. Synthesis, Physicochemical and Antioxidant Properties of Some Metal(II) Complexes of Mixed Drugs, Aspirin and Nicotinamide. (2016) Lett Health Biol Sci 1(2): 37- 42.

DOI: $10.15436 / 2475-6245.16 .010$

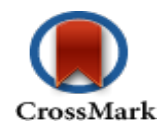

\section{Introduction}

Drug-metal complexes are of interest due to their various medicinal applications e.g. Paul Erich's organoarsenic compound for the treatment of syphilis, anti-arthritic gold preparations, and diagnostic agents for magnetic resonance imaging $(\mathrm{Gd}, \mathrm{Mn}, \mathrm{Fe})$ and many others ${ }^{[1]}$. Aspirin, is a non-steroidal, anti-inflammatory drug with antipyretic, anti-inflammatory and analgesic properties ${ }^{[2-4]}$. Nicotinamide $\left(\right.$ vitamin $\mathrm{B}_{3}$ ) is a niacin derivative, as well as a component of the coenzyme, Nicotinamide adenine dinucleotide (NAD). It is used in the treatment of various skin diseases e.g. eczema, acne vulgaris and skin can$\operatorname{cer}^{[5-7]}$. Studies also showed that it has anxiolytic (anti-anxiety) properties ${ }^{[8]}$. The deficiency of Nicotinamide results in pellagra and deterioration of the nervous system ${ }^{[9]}$. It is important to note that modification in the chemical structure of any drug, changes the pharmacological action of the drug. Thus, we envisaged that the synthesis of these mixed drug metal(II) complexes of Aspirin and Nicotinamide, would lead to novel chemotherapeutics with very good antioxidant properties as reported by some authors on metallo-antibiotics and metallo-antimalarias ${ }^{[10-12]}$. Furthermore, detailed literature search limited scanty information on mixed drug complexes of Aspirin and Nicotinamide ${ }^{[13-18]}$. Consequently, we present our findings on the synthesis, characterization and antioxidant properties of these metal(II) complexes of the mixed-drugs, Aspirin and Nicotinamide as a continuation of our search for novel metallo-drug complexes as lead compounds in drug research ${ }^{[19-24]}$. 


\section{Experimental}

\section{Materials and reagents}

Reagent grade Aspirin, Nicotinamide, Manganese(II) chloride tetrahydrate, Iron(II) tetraoxosulphate(VI) hexahydrate, Cobalt(II) chloride hexahydrate, Nickel(II) chloride hexahydrate, Copper(II) chloride tetrahydrate and Zinc acetate dihydrate were obtained from Aldrich and BDH chemicals and were used as received. Ethanol, methanol, DMSO, Dichloromethane and DMF were purified by distillation.

\section{Preparation of $\left[\mathrm{Co}(\mathrm{HL})\left(\mathrm{HL}^{3}\right) \mathrm{Cl}_{2}\right]$}

$0.92 \mathrm{~g}\left(3.89 \times 10^{-3} \mathrm{~mol}\right)$ of $\mathrm{CoCl}_{2} \cdot 6 \mathrm{H}_{2} \mathrm{O}$ was added into a stirring homogeneous solution of $0.70 \mathrm{~g}\left(3.89 \times 10^{-3} \mathrm{~mol}\right.$ of Aspirin, HL) and $0.47 \mathrm{~g}\left(3.89 \times 10^{-3} \mathrm{~mol}\right.$ of Nicotinamide, $\left.\mathrm{HL}^{3}\right)$ in $40 \mathrm{~mL}$ of hot methanol. The resulting coloured solution was then buffered to $\mathrm{pH} 9$ by the addition of six drops of triethylamine and then refluxed for six hours, during which the product formed. The product was then isolated and dried over anhydrous $\mathrm{CaCl}_{2}$. The same procedure was used for the preparation of the remaining metal complexes from their chloride, sulphate and acetate salts respectively(M(II) $=\mathrm{Mn}, \mathrm{Fe}, \mathrm{Ni}, \mathrm{Cu}$, and $\mathrm{Zn})$.

\section{Physical measurements}

IR (as $\mathrm{KBr}$ disc) and solid reflectance spectra were recorded on a FT-IR spectrum BX and a Perkin-Elmer $\lambda 25$ spectrophotometer respectively. The melting points of the ligands and the complexes were determined using a Gallenkamp melting point apparatus; percentage metal was determined titrimetrically, while molar conductivity measurements of $1 \times 10^{-3} \mathrm{M}$ solutions in DMSO were carried out using an electrochemical analyzer consort C933. Room temperature magnetic moment susceptibilities measurements were determined using a Sherwood susceptibility balance MSB Mark 1 at room temperature of $303 \mathrm{~K}$.

\section{Antioxidant capacity determination}

CUPRAC assay was used ${ }^{[25]}$ with slight modification.
The reagent used contained $1 \mathrm{~mL}$ of $10 \mathrm{mM} \mathrm{CuCl}_{2} .2 \mathrm{H}_{2} \mathrm{O}, 1 \mathrm{~mL}$ of $7.5 \mathrm{mM}, 1,10$ - phenanthroline and $1 \mathrm{~mL}$ of $1 \mathrm{M}$ ammonium acetate. This solution was then added to a test-tube containing $0.6 \mathrm{~mL}$ of distilled water and $0.5 \mathrm{~mL}$ of sample solution with the same concentration $(0.01 \mathrm{~g} / \mathrm{mL}$ methanol) to achieve a final volume of $4.1 \mathrm{~mL}$. This text mixture was afterwards incubated for 30 minutes at room temperature, and the absorbance read at $450 \mathrm{~nm}$ spectrophotometrically against the blank. The blank solution contained $1 \mathrm{~mL}$ of $10 \mathrm{mM} \mathrm{CuCl}_{2} .2 \mathrm{H}_{2} \mathrm{O} ; 1 \mathrm{~mL}$ of 7.5 $\mathrm{mM}, 1,10$-phenanthroline and $1 \mathrm{~mL}$ of $1 \mathrm{M}$ ammonium acetate solution as well as $0.6 \mathrm{~mL}$ of distilled water, while Ascorbic acid was used as the standard. The experiment was conducted in triplicate and the percentage (\%) reducing antioxidant capacity was expressed as:

$\%$ reducing antioxidant capacity $=($ Atest $/$ Ablank

-1) $\times 100^{[25]}$

Where $A_{\text {test }}$ is the absorbance of sample solution and $A_{\text {blank }}$ is the absorbance of the blank solution.

\section{Results and Discussion}

\section{Analytical data}

The melting points of the drugs and their metal(II) complexes were distinctively different, that is, Aspirin decomposed at $136^{\circ} \mathrm{C}$, Nicotinamide melted at $130^{\circ} \mathrm{C}$, and the metal complexes decomposed above $180^{\circ} \mathrm{C}$, due to coordination. In addition, the percentage metal analysis and conductance measurements corroborated the formula mass mostly as [M(HL) $\left.\left(\mathrm{HL}^{3}\right) \mathrm{X}_{2}\right]$, since the molar conductance values were in the range $19.60-46.80 \Omega^{-1} \mathrm{~cm}^{2} \mathrm{~mol}^{-1}$, indicative of a non-electrolyte. However, the Mn(II) complex had the formula mass [ $\{\mathrm{Mn}(\mathrm{HL})$ $\left.\left.\left(\mathrm{HL}^{3}\right)\right\}_{2}\left(\mathrm{H}_{2} \mathrm{O}\right) \mathrm{Cl}\right] \mathrm{Cl}$ and a molar conductance value of 69.20 $\Omega^{-1} \mathrm{~cm}^{2} \mathrm{~mol}^{-1}$, which was indicative of a $1: 1$ electrolyte ${ }^{[26]}$. The yields of the metal complexes were moderate $(30-50 \%)$ with the exception of the Mn(II) complex which had a low yield of $10 \%$ attributed to its probable polymeric nature (Table 1 ). The equation and mechanism for the formation of this complex are shown in Figures 1 and 2 respectively.

Table 1: Analytical data of Aspirin and Nicotinamide and their metal(II) complexes 3.

\begin{tabular}{|c|c|c|c|c|c|c|c|}
\hline Complexes & F. Mass & Color & M.pt $\left({ }^{\circ} \mathrm{C}\right)$ & \%Yield & $\%$ M (Exp) & $\Lambda_{\mathrm{m}}$ & $\mu_{\text {eff }}($ B.M) \\
\hline HL & 180.16 & White & 136 & - & - & - & - \\
\hline $\mathbf{H L}^{3}$ & 122.12 & White & 130 & - & - & - & - \\
\hline$\left[\left\{\mathrm{Mn}(\mathrm{HL})\left(\mathrm{HL}^{3}\right)\right\}_{2}\left(\mathrm{H}_{2} \mathrm{O}\right) \mathrm{Cl}\right] \mathrm{Cl} .2 \mathrm{H}_{2} \mathrm{O}$ & 839.56 & white & $320(\mathrm{D})$ & 10 & $13.10(11.39)$ & 69.2 & 5.38 \\
\hline$\left[\mathrm{Fe}(\mathrm{HL})\left(\mathrm{HL}^{3}\right) \mathrm{SO}_{4}\right]$ & 454.90 & Red & 250(D) & 30 & $12.23(12.28)$ & 29.3 & 5.50 \\
\hline$\left[\mathrm{Co}(\mathrm{HL})\left(\mathrm{HL}^{3}\right) \mathrm{Cl}_{2}\right]$ & 432.92 & Purple & $300(\mathrm{D})$ & 50 & $13.55(13.61)$ & 46.8 & 5.60 \\
\hline$\left[\left\{\mathrm{Ni}(\mathrm{HL})\left(\mathrm{HL}^{3}\right)\right\} 2 \mathrm{Cl}_{2}\right]$ & 792.98 & green & $320(\mathrm{D})$ & 30 & $14.81(12.54)$ & 19.7 & 4.70 \\
\hline$\left[\mathrm{Cu}(\mathrm{HL})\left(\mathrm{HL}^{3}\right) \mathrm{Cl}_{2}\right]$ & 436.84 & blue & $220(\mathrm{D})$ & 50 & $14.47(14.44)$ & 40.7 & 1.78 \\
\hline$\left[\mathrm{Zn}(\mathrm{HL})\left(\mathrm{HL}^{3}\right)\left(\mathrm{CH}_{3} \mathrm{COO}\right)\left(\mathrm{H}_{2} \mathrm{O}\right)\right]$ & 445.36 & White & $188(\mathrm{D})$ & 30 & $14.74(14.68)$ & 23.3 & $\mathrm{D}$ \\
\hline
\end{tabular}

Keywords: (D): Decomposition temperature; M: Metal; Exp: Experimental; HL: Aspirin;

$\mathrm{HL}^{3}$ : Nicotinamide; F. mass: Formula mass; $\Lambda_{\mathrm{m}}: \Omega^{-1} \mathrm{~cm}^{2} \mathrm{~mol}^{-1}$ 


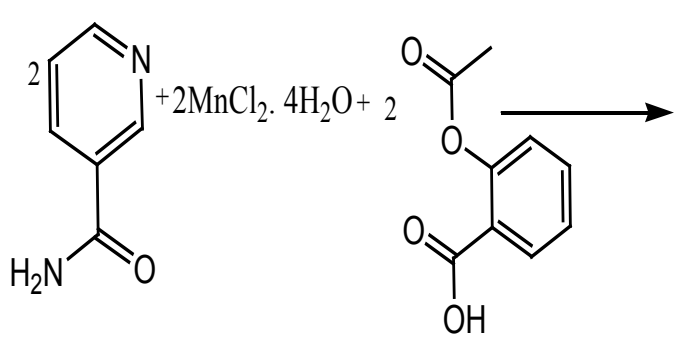

Figure1: Equation for the formation of the Mn(II) complex.
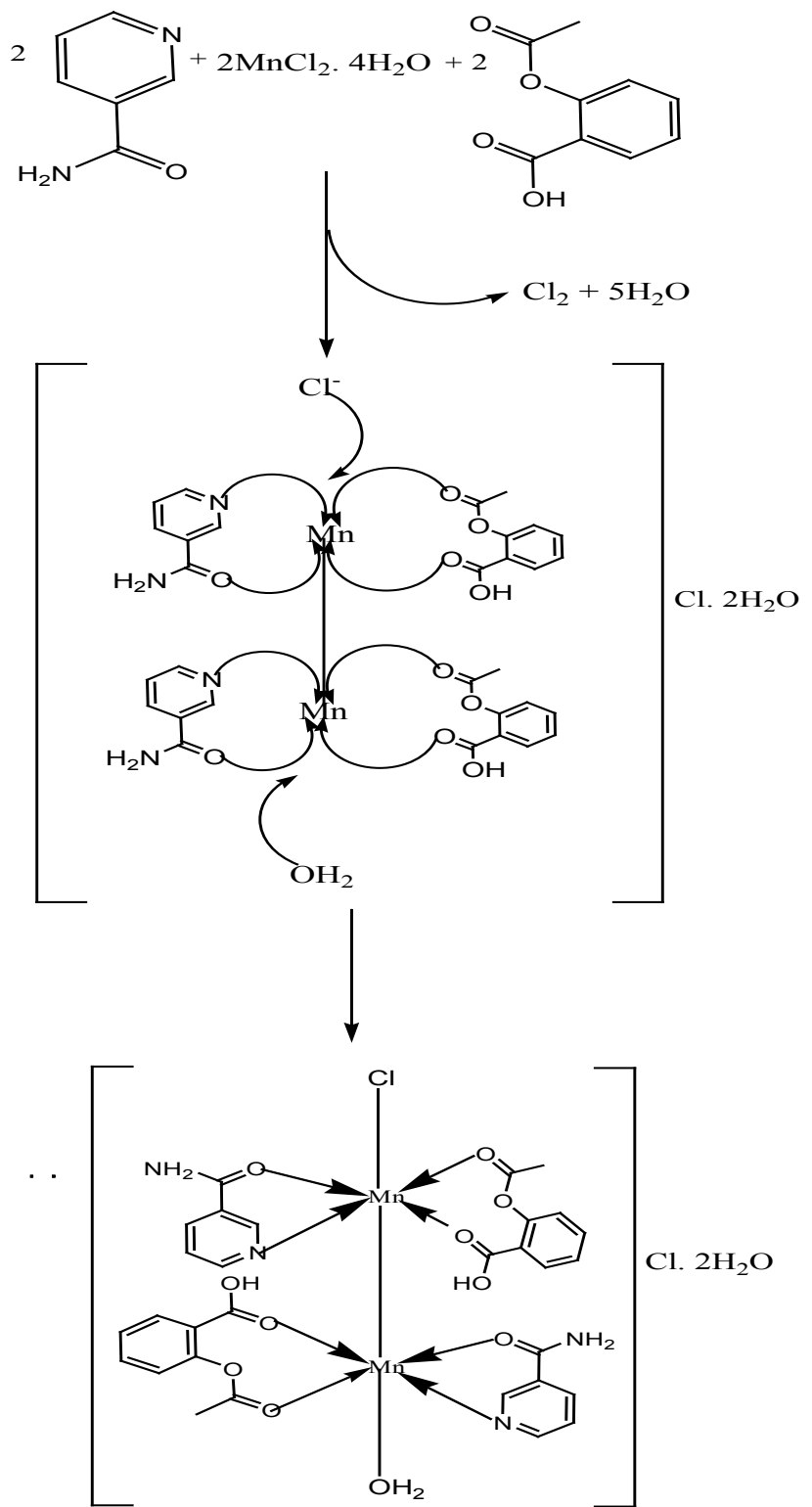

Figure 2: Mechanism for the formation of the Mn(II) complex.
Cl. $2 \mathrm{H}_{2} \mathrm{O}+\mathrm{Cl}_{2}+5 \mathrm{H}_{2} \mathrm{O}$
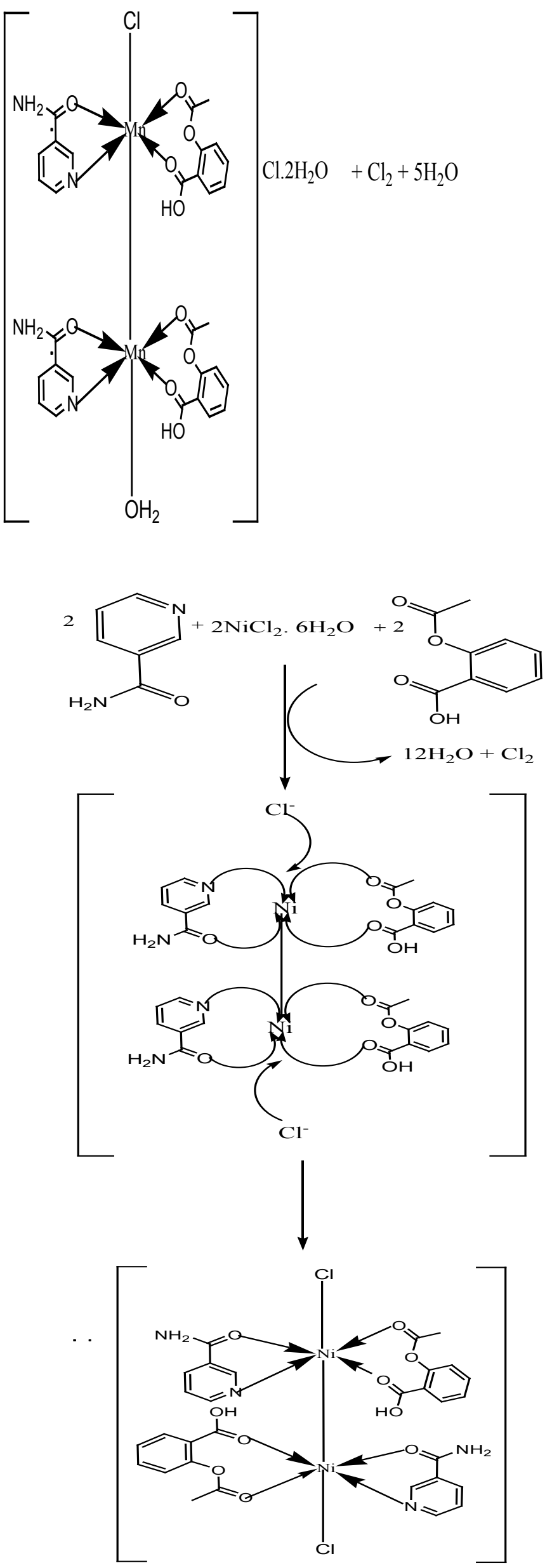

Figure 3: Mechanism for the formation of the Ni(II) complex. 


\section{Electronic spectra and magnetic moments of the compounds}

The electronic spectra for the metal free Aspirin (HL) and Nicotinamide $\left(\mathrm{HL}^{3}\right)$ were characterized by three bands at $26.25 \mathrm{kK}, 30.30-37.80 \mathrm{kK}$, and $41.49-51.02 \mathrm{kK}$ due to $\mathrm{n} \rightarrow \pi^{*}$, $\pi \rightarrow \pi^{*}$ and CT transitions respectively. The $\mathrm{Mn}$ (II) complex showed an absorption band at $15.04 \mathrm{kK}$ assigned to ${ }^{6} \mathrm{~A}_{1} \rightarrow{ }^{4} \mathrm{~T}_{1 \mathrm{~g}}$ transition indicative of a 6-coordinate octahedral geometry. An observed room temperature moment of 5.38 B. M indicated antiferromagnetism ${ }^{[27]}$ operating through a dimeric structure [Figure 2], since a moment of 5.92 B.M is usually expected for high spin, octahedral Mn(II) compounds. This is because the ground term is an A, with no higher $\mathrm{T}$ term of the same multiplicity and thus, orbital contribution is zero. Two absorption bands were observed at $17.20 \mathrm{kK}$ and $20.83 \mathrm{kK}$ for the Fe(II) complex due to ${ }^{5} \mathrm{~B}_{2 \mathrm{~g}} \rightarrow{ }^{5} \mathrm{~B}_{1 \mathrm{~g}}$ and ${ }^{5} \mathrm{~B}_{2 \mathrm{~g}} \rightarrow{ }^{5} \mathrm{~A}_{1 \mathrm{~g}}$ transitions of high spin octahedral geometry. This complex expectedly had a complimentary moment of 5.50 B.M ${ }^{[23]}$. Similarly, the Co(II) complexes exhibited bands at $15.39 \mathrm{kK}, 17.04 \mathrm{kK}$ and $20.88 \mathrm{kK}$ which were assigned to ${ }^{4} \mathrm{~T}_{1 \mathrm{~g}}(\mathrm{~F}) \rightarrow{ }^{4} \mathrm{~T}_{2 \mathrm{~g}}(\mathrm{~F}),{ }^{4} \mathrm{~T}_{1 \mathrm{~g}}(\mathrm{~F}) \rightarrow{ }^{4} \mathrm{~A}_{2 \mathrm{~g}}(\mathrm{~F})$ and ${ }^{4} \mathrm{~T}_{1 \mathrm{~g}}(\mathrm{~F}) \rightarrow$ ${ }^{4} \mathrm{~T}_{1 \mathrm{~g}}(\mathrm{P})$ transitions of 6-coordinate, octahedral geometry. A room temperature magnetic moment of 5.60 B.M was indicative of a high spin octahedral geometry ${ }^{[27]}$. In contrast, the $\mathrm{Ni}(\mathrm{II})$ complex exhibited an absorption band at $15.20 \mathrm{kK}$, assigned to ${ }^{3} \mathrm{~A}_{2 \mathrm{~g}}$ $\rightarrow{ }^{3} \mathrm{~T}_{1 \mathrm{~g}}(\mathrm{~F})$ of a six coordinate, high spin octahedral geometry. Room temperature magnetic moments in the range 2.8 - 3.3 B.M are expected for monomeric, high spin octahedral Ni(II) complexes. However, a moment of 4.70 B.M was observed for this complex. This is suggestive of antiferromagnetism ${ }^{[28]}$ operating through a Ni-Ni bond in a dimeric structure [Figure 3], such that each Ni atom had a moment of 2.35 B.M. The $\mathrm{Cu}$ (II) complex had a single absorption band at $15.24 \mathrm{kK}$ assigned to ${ }^{2} \mathrm{E}_{\mathrm{g}} \rightarrow{ }^{2} \mathrm{~T}_{2 \mathrm{~g}}$ transitions typical of an octahedral geometry, since tetrahedral $\mathrm{Cu}$ (II) complexes usually have a single band below $10.0 \mathrm{kK}$. An observed moment of 1.78 B.M was normal for a mononuclear, octahedral $\mathrm{Cu}(\mathrm{II})$ complex $^{[29]}$. The $\mathrm{Zn}$ (II) complex exhibited only $\mathrm{M} \rightarrow \mathrm{L} \mathrm{CT}$ transitions at 41.49 and $49.26 \mathrm{kK}$, and it was expectedly diamagnetic with a moment of 0.15 B.M ${ }^{[26]}$.

\section{Infrared spectroscopy of the compounds}

The relevant bands in IR spectra of Aspirin (HL) and Nicotinamide $\left(\mathrm{HL}^{3}\right)$ and their complexes are presented in Table 2. The medium and broad band at 3370 and $3170 \mathrm{~cm}^{-1}$ respectively in Nicotinamide was assigned as $v(\mathrm{NH})$ band. This band shifted to lower frequencies of $3068-3206 \mathrm{~cm}^{-1}$ in the complexes, due to intra-hydrogen bonding interaction between the H-atom of the amide group and its carbonyl O-atom. The sharp bands at 1576 and $1593 \mathrm{~cm}^{-1}$ in the Nicotinamide were assigned as $v \mathrm{C}$ $=\mathrm{N}$ stretching vibrations, and they shifted to a lower frequencies of $1533-1572 \mathrm{~cm}^{-1}$ in the complexes thus confirming coordination of the pyridinyl nitrogen atom of the Nicotinamide ${ }^{[26]}$. The bands in the range $1606-1754 \mathrm{~cm}^{-1}$ in the Aspirin and Nicotinamide respectively were assigned as $v \mathrm{C}=\mathrm{O}$. These bands shifted to $1621-1725 \mathrm{~cm}^{-1}$ in the spectra of the metal(II) complexes due to coordination of the carbonyl oxygen atoms of the Nicotinamide and Aspirin ${ }^{[30]}$. In addition, the new bands in the range $480-586 \mathrm{~cm}^{-1}$ and $300-308 \mathrm{~cm}^{-1}$ were assigned as $v(\mathrm{M}$ - N)/v(M - O) and $v(\mathrm{M}-\mathrm{Cl})$ respectively due to coordination of the pyridinyl $\mathrm{N}$-atom of the Nicotinamide, carbonyl oxygen atoms of both drugs, and chlorine atoms to metal ions. However, these bands were absent in the spectra of the Nicotinamide and Aspirin, confirming coordination in the metal complexes.

Table 2: Infrared $\left(\mathrm{cm}^{-1}\right)$ and Electronic spectral data of and their metal(II) complexes.

\begin{tabular}{|c|c|c|c|c|c|}
\hline Compound & $\mathrm{vN}-\mathrm{H} / \mathrm{OH}$ & $\mathrm{vC}=\mathrm{O}$ & $\mathrm{vC}=\mathrm{N}$ & vM-O/ vM-N & Absorption Band (kK) \\
\hline HL & $3457 b$ & $1754 \mathrm{~s} \quad 1606 \mathrm{~s}$ & - & - & 51.0241 .4933 .00 \\
\hline $\mathbf{H L}^{3}$ & $3370 \mathrm{~m} 3170 \mathrm{~b}$ & $1699 \mathrm{~s} 1621 \mathrm{~s}$ & $1593 \mathrm{~s} 1576 \mathrm{~s}$ & - & $\begin{array}{ll}51.02 & 41.49 \\
30.30 & 26.25 \\
\end{array}$ \\
\hline$\left[\left\{\mathrm{Mn}(\mathrm{HL})\left(\mathrm{HL}^{3}\right)\right\}_{2}\left(\mathrm{H}_{2} \mathrm{O}\right) \mathrm{Cl}\right] \mathrm{Cl} .2 \mathrm{H}_{2} \mathrm{O}$ & $3206 \mathrm{w}$ & $1709 \mathrm{~s} \quad 1651 \mathrm{w}$ & $1623 \mathrm{~s} 1601 \mathrm{~s}$ & 523 & 35.7115 .04 \\
\hline$\left[\mathrm{Fe}(\mathrm{HL})\left(\mathrm{HL}^{3}\right) \mathrm{SO}_{4}\right]$ & $3413 b$ & $1621 \mathrm{~s} \quad 1602 \mathrm{~s}$ & $1569 \mathrm{~s} 1537 \mathrm{~s}$ & $535 \mathrm{~s} 483 \mathrm{~s}$ & 45.4626 .1820 .8317 .20 \\
\hline$\left[\mathrm{Co}(\mathrm{HL})\left(\mathrm{HL}^{3}\right) \mathrm{Cl}_{2}\right]$ & $3399 w$ & $1667 \mathrm{~s} \quad 1601 \mathrm{~s}$ & $1564 \mathrm{~s}$ & $586 \mathrm{~s} 480 \mathrm{~s}$ & $\begin{array}{l}30.8620 .88 \\
17.0415 .39 \\
\end{array}$ \\
\hline$\left[\left\{\mathrm{Ni}(\mathrm{HL})\left(\mathrm{HL}^{3}\right)\right\}_{2} \mathrm{Cl}_{2}\right]$ & $3197 \mathrm{w}$ & $1667 \mathrm{w} 1601 \mathrm{~s}$ & $1563 \mathrm{~s} 1533 \mathrm{~s}$ & $502 \mathrm{~s}$ & 30.9615 .20 \\
\hline$\left[\mathrm{Cu}(\mathrm{HL})\left(\mathrm{HL}^{3}\right) \mathrm{Cl}_{2}\right]$ & $3403 b$ & $1725 \mathrm{~s} \quad 1606 \mathrm{~s}$ & $1572 \mathrm{~s}$ & $551 \mathrm{~s}$ & 33.0115 .24 \\
\hline
\end{tabular}

Keyword: b: broad; s: strong; w: weak; m: medium; HL: Aspirin; $\mathrm{HL}^{3}$ : Nicotinamide

\section{Antioxidant activities of the compounds}

Transition metals (copper, chromium, cobalt, vanadium, cadmium, arsenic, nickel) promote oxidation by acting as catalysts of free radical reactions. These redox-active transition metals transfer single electrons during changes in oxidation states. Chelation of metals by certain compounds decreases their pro-oxidant effects by reducing their redox potentials, thus stabilizing the oxidized form of the metal and also sterically hindering the formation of the metal hydro peroxide complex ${ }^{[31]}$. The antioxidant activities $(\%$ inhibition) of the drugs and their metal(II) complexes were compared to that of the Ascorbic acid (standard). The results revealed that the drugs, Nicotinamide, and Aspirin, had the best activities of about 70\%, which was greater than those of the metal(II) complexes. The order of decreasing activity of the metal complexes was $\mathrm{Mn}>\mathrm{Co}>\mathrm{Fe}>(\mathrm{Cu}=\mathrm{Ni})>\mathrm{Zn}$. (Table 3). 
Table 3: Antioxidant data of Aspirin, Nicotinamide and their metal(II) complexes.

\begin{tabular}{|c|c|c|}
\hline Complex & Absorbance(error) nm & $\%$ Inhibition \\
\hline HL & $0.033(0.001)$ & 68.75 \\
\hline $\mathbf{H L}^{3}$ & 0.035 & 72.20 \\
\hline$\left[\left\{\mathrm{Mn}(\mathrm{HL})\left(\mathrm{HL}^{3}\right)\right\}_{2}\left(\mathrm{H}_{2} \mathrm{O}\right) \mathrm{Cl}\right] \mathrm{Cl} .2 \mathrm{H}_{2} \mathrm{O}$ & 0.030 & 62.50 \\
\hline$\left[\mathrm{Fe}(\mathrm{HL})\left(\mathrm{HL}^{3}\right) \mathrm{SO}_{4}\right]$ & $0.020(0.007)$ & 41.67 \\
\hline$\left[\mathrm{Co}(\mathrm{HL})\left(\mathrm{HL}^{3}\right) \mathrm{Cl}_{2}\right]$ & 0.027 & 56.25 \\
\hline$\left[\left\{\mathrm{Ni}(\mathrm{HL})\left(\mathrm{HL}^{3}\right)\right\} 2 \mathrm{Cl}_{2}\right]$ & 0.018 & 37.50 \\
\hline$\left[\mathrm{Cu}(\mathrm{HL})\left(\mathrm{HL}^{3}\right) \mathrm{Cl}_{2}\right]$ & $0.018(0.007)$ & 37.50 \\
\hline$\left[\mathrm{Zn}(\mathrm{HL})\left(\mathrm{HL}^{3}\right)\left(\mathrm{CH}_{3} \mathrm{COO}\right)\left(\mathrm{H}_{2} \mathrm{O}\right)\right]$ & $0.016(0.001)$ & 34.03 \\
\hline$A_{1}$ & 0.010 & 17.20 \\
\hline
\end{tabular}

HL: Aspirin; $\mathrm{HL}^{3}$ : Nicotinamide; $\mathrm{A}_{1}$ : ascorbic acid

\section{Conclusion}

Some divalent metal complexes of the mixed drugs-Aspirin and Nicotinamide were synthesized and characterized (M $=\mathrm{Mn}, \mathrm{Fe}, \mathrm{Co}, \mathrm{Ni}, \mathrm{Cu}$ and $\mathrm{Zn}$ ). The metal complexes were covalent, mostly monomeric and paramagnetic with octahedral geometry. Furthermore, antioxidant studies revealed that the $\mathrm{Mn}$ (II) complex showed the best antioxidant activity among the metal complexes.

Acknowledgement: The University of Ibadan, Ibadan, Nigeria is acknowledged for the provision of research chemicals and Bowen University is acknowledged for a sabbatical position.

Competing interests: The authors have declared that no competing interests exist.

\section{References}

1. Saied, A., Anvarhusein, A., Isab, S. A., et al. Perspectives in bioinorganic chemistry of some metal based therapeutic agents. (2006) Polyhedron 25(7): 1633-1645.

2. Ioannides, C., Stone, A.N., Breacker, P.J., et al. Impairment of absorption of ascorbic acid following ingestion of aspirin in guinea pigs. (1982) Biochem Pharmacol 31(24): 4035-4038.

3. Cuzick, J., Thorat, M.A. Bosetti, C. Estimates of benefits and harms of prophylactic use of aspirin in the general population. (2014) Annals of oncology 26: 47-57.

4. Burke, A., Smyth, E., FitzGerald, G.A. et al. Analgesic Antipyretic and Anti-inflammatory Agents. (2006) The Pharmacological Basis of Therapeutics (11 Ed.) New York: McGraw-Hill 671-716.

5. Chan, A.T., Arber, N., Burn, J., et al. Aspirin in the chemoprevention of colorectal neoplasia: an overview. (2012) Cancer prevention research (Philadelphia) 5(2): 164-178.

6. McCormick, D.B. Vitamin, structure and function of In: Encyclopedia of molecular biology and molecular medicine, Meyers RA (Ed.). (1997) Weinheim VCH 6: 244-252.

7. McCormick, D.B. Niacin In: modern nutrition in health and disease (6thedn). (1998) Philadelphia and Ferbiger 370-375.

8. Tallman, J.F., Paul, S.M., Skolnick, P., et al. Receptors for the age of anxiety: pharmacology of the benzodiazepines. (1980) Science 207(4428): 274-281.

9. Reynold, F.E., Anne, B.P. Martindale, the extra Pharmacopoeia, 28th edition. (1982) the Pharmaceutical Press London 1635-1688.

10. Ogunniran, K.O., Ajanaku, K.O., James, O.O., et al. Synthesis, characterization, antimicrobial activity and toxicology study of some metal complexes of mixed antibiotics. (2008) African Journal of Pure and Applied Chemistry 2(7): 069-074.
11. Adediji, J.F., Olayinka, E.T., Adebayo, M.A., et al. Antimalarial mixed ligand metal complexes: Synthesis, physicochemical and biological activities. (2009) International journal of physical sciences 4(9): 529-534.

12. Arayne, S., Sultana, N., Haroon, U., et al. Synthesis, characterization, antibacterial and anti-Inflammatory activities of enoxacin metal complexes. (2009) Bioinorg Chem Appl 2009: 914105.

13. Obaleye, M.O., Tella A.C., Obaleye J.A. Synthesis, Characterization and Antimicrobial Activity of Mixed Pyrimethamine-Vitamin Metal Drug Complexes. (2011) African Journal of Physical Science 4(2): 50-55.

14. Lawal, A., Obaleye, J.A., Tella A.C., et al. Synthesis and Characterization of Mixed Zinc(II) Complex of Ascorbic Acid and Thiamine Hydrochloride. (2012) Science Focus 17(2): 217-221.

15. Lawal, A., and Obaleye, J. A. Synthesis, Spectroscopic characterization and Antimicrobial study of mixed thiamine-Nicotinamide metal complexes. (2013) Nig J Pure \& Appl Sci 26: 2438-2445.

16. Fizea, S.M., Musa, F.H., and Fidhel, H.A. Synthesis and spectral studies of metal complexes with 3, 4, 6, 7-0, 0, 0, 0-tetrakis-(Carboxy(chloro)methyl)-L-Ascorbic acid. (2014) Eur Chem Bull 3(9): 915-919.

17. Zhang, C.G., Duan, C.Y., Hu, Q., et al. Self-assembly in transition metal complexes: structural characterization of a copper histamine nitrate $\left[\mathrm{Cu}(\mathrm{II})(\mathrm{him})_{2}\left(\mathrm{NO}_{3}\right)_{2}\right]$. (1999) Journal of Chemical Crystallography 29(11): 1153-1155.

18. Bivián-Castro, E.Y., López, M.G., Pedraza-Reyes, M., et al. Synthesis, characterization, and biological activity studies of copper(II) mixed compound with histamine and nalidixic acid. (2009) Bioinorg Chem Appl 2009: 603651.

19. Osowole, A.A., Agbaje, O.B., Ojo, B.O. Synthesis, characterization and antibacterial properties of some heteroleptic metal(II) complexes of paracetamol and vanillin. (2014) Asian J Pharm Clin Res 7(3): 145-149. 20. Osowole, A. A., Wakil, S. M., Malumi, E.O. Synthesis, characterization, antioxidant and antimicrobial activities of some metal(II) complexes of the mixed-ligand, Vitamin $B_{2}$ and Benzoic acid. (2015) Elixir Appli. Chem 79: 30370-30374.

21. Osowole, A.A., Agbaje, O.B.A.,Wakil, S.M. Synthesis, characterization and biological activity of some mixed metal(II) complexes of Paracetamol and Benzoic acid. (2015) International Journal of Applied Medical Sciences 1: 77-87.

22. Osowole, A. A., Malumi, E.O., Wakil, S.M., et al. Synthesis, characterization, antioxidant and antimicrobial activities of some mixeddrug metal(II) complexes of vitamins B2 and B3. (2015) International Journal of Applied Medical Sciences 1: 88-97.

23. Osowole, A. A., Wakil, S.M., and Alao, O. K. Synthesis, characterization and antimicrobial activity of some mixed Trimethoprim-Sulfamethoxazole metal drug complexes. (2015) World Applied Sciences Journal 3(2): 336-342. 
24. Osowole, A.A., and Odutemu, A.E. Synthesis, Magnetic, Spectral and Antibacterial Properties of Some Metal(II) Complexes of Mixed Drugs, Aspirin and Vitamin B2. (2016) Lett Health Biol Sci 1(2): 1- 4. 25. Apak, R., Guclu, K., Ozyurek, M., et al. Novel total antioxidant capacity index for dietary polyphenols and vitamins $\mathrm{C}$ and $\mathrm{E}$, using their cupric ion reducing capability in the presence of neocuproine: CUPRAC method. (2004) J Agric Food Chem 52(26): 7970.

26. Al-Saif, F.A., Refat, M.S. Ten metal complexes of vitamin B3/ niacin: Spectroscopic, thermal, antibacterial, antifungal, cytotoxicity and antitumor studies of $\mathrm{Mn}(\mathrm{II}), \mathrm{Fe}(\mathrm{III}), \mathrm{Co}(\mathrm{II}), \mathrm{Ni}(\mathrm{II}), \mathrm{Cu}(\mathrm{II}), \mathrm{Zn}(\mathrm{II})$, $\mathrm{Pd}(\mathrm{II}), \mathrm{Cd}(\mathrm{II}), \mathrm{Pt}(\mathrm{IV})$ and $\mathrm{Au}(\mathrm{III})$ complexes. (2012) J of Molecular Structure 1021: 40-52.

27. Karipcin, F., Dede, B., Percin-Ozkorucuklu, S., et al. Mn(II), Co(II) and $\mathrm{Ni}(\mathrm{II})$ complexes of 4-(2-thiazolylazo)resorcinol: Syntheses, characterization, catalase-like activity, thermal and electrochemical behaviour. (2010) Dyes and Pigments 84(1): 14-18.

28. Osanai, K., Okazawa, A., Nogami, T., et al. Strong ferromagnetic exchange couplings in $\mathrm{Cu}(\mathrm{II})$ and $\mathrm{Ni}(\mathrm{II})$ complexes with a paramagnetic tridentate chelate ligand, 2,2-bipyridin-6-yl tert-butyl nitroxide. (2006) J Am Chem Soc 128(43): 14008-14009.

29. Raman, N., Ravichandran, S., Thangaraja, C. Cu(II), Co(II), Ni(II) and $\mathrm{Zn}(\mathrm{II})$ complexes of Schiff base derived from benzil-2,4-dinitrophenyl hydrazone with aniline. (2004) J Chem Soc (Indian Academic Society) 116(4): 215-219.

30. Lawal, A., Obaleye, J.A. Synthesis, characterization and antibacterial activity of aspirin and Paracetamol-metal complexes. (2007) Biokemistri 19(1): 9-15.

31. Halliwell, B., Gutteridge, J.M.C. Oxygen toxicology, oxygen radicals, transition metals and disease. (1984) Biochem J 219(1): 1-4. 